\title{
Literature as a Digital Literation Culture Strengthen
}

\author{
Zuliyanti $^{1}$, Mukh Doyin ${ }^{2}$ \\ Universitas Negeri Semarang ${ }^{1,2}$ \\ \{zuliyanti@mail.unnes.ac.id ${ }^{1}$, mukhdoyin@mail.unnes.ac.id²
}

\begin{abstract}
Learning literature means learning the culture of a nation. Literature is a miniature of people's life that cannot be separated from culture. Literary content is closely related to life which can be used as a means of teaching the values of life to the audience. Literature has its own charm for its connoisseurs. Literary language is able to provide a stimulus for its readers to literate. Literary presentation is not only in printed form, but nowadays literature in electronic media has developed. The presence of literature in electronic media contributes greatly to the development of a literacy culture. Especially in the midst of the Covid-19 pandemic which is endemic in several countries. Literature is an option that readers can enjoy while on the move at home. The number of literary lovers has also increased. The culture of reading has begun to rise again and is rife in some circles. This means that the weak digital literacy culture in Indonesia is increasing. Literature is able to become an effective literacy culture reinforcer.
\end{abstract}

Keywords: literature, culture, and digital literacy.

\section{Introduction}

The problem of literacy is still a hot topic of conversation in Indonesia. Literacy culture begins to weaken and occurs in all circles. People are reluctant to read and even write so that their literacy skills are low. Literacy activities in this case are reading and writing. Literacy (reading and writing) is the "heart" of education because literacy contains information, knowledge and knowledge, as well as messages or values of noble life that are able to form a person with character [1]. Therefore, not a few people lack information and knowledge. Their knowledge only relies on what they hear, not by reading.

The rapid development of technology has an impact on the development of increasingly sophisticated communication tools. People can easily get information from the internet. However, this sophistication has not been fully utilized. People are still lazy to read articles or information from the internet or digital literacy. Whereas someone who is capable of literacy is not only able to read and write but will also support someone to think [2]. The condition of digital literacy in Indonesia is classified as low, which is only 8\% [3]. This condition is inversely proportional to the development of the number of media recorded to have increased rapidly, reaching around 43,400, while only 243 registered media registered in the Press Council. People easily get information from various existing media, regardless of whether the news is official or not [4]. 
The presence of various devices that can connect to the internet network also diverts people's attention from books to devices. This means that digital devices have actually managed to attract attention and become a necessity for everyone. Seeing this condition, it should be appropriate if digital literacy can be improved by presenting interesting, light, and meaningful writing and reading. Most of the people are interested in using the internet for social media, consumptive activities, and some daily necessities. Some people are also interested in watching films or reading literary works. It is not surprising that by reading literature, people will feel happy because they can be entertained.

Learning literature can also be interpreted as learning culture because literature is never separated from a culture. Literary work is a cultural record of a certain society which includes organizations, institutions, law, work ethic, art, religion, and so on. Therefore, studying literature means learning the culture of the producing community [5\&6]. The contents in literature are closely related to life which can be used as a means of teaching the values of life to the audience. Life stories or stories that are featured in literature are miniatures of life that are built with all cultures from the life of the author.

Literature that is presented in digital form is certainly more interesting than in book form. People will easily read literary works whenever and wherever. This means that literature can be used as a smart strategy to "lure" readers to be more interested in digital literacy. With technology, people can write and read literary works to their heart's content. Digital literacy activities with literature can be used as a first step to revive literacy culture. Later, readers are expected to read news or other information on the internet. Thus, the digital literacy culture will gradually improve and be well-formed.

\section{Digital literacy}

The concept of literacy includes not only the ability to read but read with meaning and understand, while digital literacy includes the mastery of ideas, not the ability to press buttons only. Digital literacy is the ability to understand and use information from various digital sources [7]. Digital literacy is also defined as the ability to use technology and information from digital devices effectively and efficiently in various contexts such as academics, careers, and everyday life [8]. Digital literacy can also be interpreted as media literacy. "Media literacy consists of a series of communication competencies including the ability to access, analyze, evaluate, and communicate information in various forms of printed and non-printed messages" [9]. Every individual needs to understand that digital literacy is as important as reading, writing, arithmetic, and other disciplines. "Digital literacy is the interest, attitude, and ability of individuals in using digital technology and communication tools to access, manage, integrate, analyze and evaluate information, build new knowledge, and communicate in order to participate effectively" [10].

Digital literacy will create a society with a creative-critical mindset and perspective. They will not be easily consumed by provocative issues, become victims of hoax information, or victims of digital-based fraud. Thus, the social and cultural life of the community will tend to be safe and conducive. Building a digital literacy culture needs to involve the active role of the community together. The success of building digital literacy is an indicator of achievement in the fields of education and culture.

Being digital literate means being able to process various information, be able to understand messages and communicate effectively with others in various forms. In this case, the intended form includes creating, collaborating, communicating, and working according to 
ethical rules, and understanding when and how technology must be used to be effective in achieving goals. This includes awareness and critical thinking about the various positive and negative impacts that may occur due to the use of technology in everyday life. Digital media consists of various forms of information at once, such as voice, writing, and images. "Digital literacy should be more than just the ability to use various digital sources effectively. Digital literacy is also a form of particular way of thinking."[11] It can be concluded that digital literacy is the ability to understand and use information from various digital sources with the aim of increasing the reader's knowledge digitally."

\section{The Role of Literature in Digital Literacy}

Literature as a nation's cultural heritage deserves to be preserved. One of them is by inheriting literature by introducing, making an inventory, and documenting literature for the younger generation. Literary works are very varied and can be enjoyed because of their light and beautiful language. These literary works include poetry, short stories, novels and dramas.

Literature can "captivate" readers who can currently be presented by taking advantage of technological developments. Literature digitization can be done with the aim that literature can be enjoyed by readers anytime and anywhere. Readers no longer have to read in printed book form, but digitalization can be a solution to preserving literature. The role of literature to improve digital literacy is (1) attracting reading interest, (2) increasing readers' love for digital information, (3) avoiding digital hoax information, and (4) taking digital literature inventory.

Literature can increase the reader's interest in literacy. A literary language that is interesting, light, and beautiful can make readers happy to read. The hope is that reading literature will affect the reader's love for literacy by writing literary works because reading and writing are correlated. In addition, the growing interest in reading literature is expected to increase readers' curiosity to obtain information digitally. Digital information is needed by smart and critical readers in order to distinguish between hoax and non-hoax information. Not a few news or information is present digitally and the truth is uncertain. Readers who are less observant will receive hoax news and will not be able to distinguish between true and hoax news.

Literary digitization has become a means of inventorying literature that is almost extinct and is disappearing. Literature which is rich in the noble values of life has not been properly inventoried. This condition will trigger the disappearance of literature from civilization in Indonesian society. Literary digitization is said to be more effective in documenting literature because it will not be lost, damaged, or lost.

The scope of digital literacy is very broad. Digital literacy involves several aspects, namely (1) the assembly of knowledge, namely the ability to build information from various reliable sources. (2) The ability to present information includes critical thinking in understanding information with awareness of the validity and completeness of sources from the internet. (3) Ability to read and understand non-sequential and dynamic information material. (4) Awareness of the importance of conventional media and linking it to networked media (internet). (5) Awareness of access to networks of people who can be used as a source of referrals and help. (6) Use of filters for incoming information. (7) Feel comfortable and have access to communicate and publish information [12]. Based on this description, it can be concluded that the digitization of literature can improve digital literacy skills, namely to increase interest in reading, understanding and using information from various digital sources 
including the ability to access, analyze, evaluate, and communicate information in various forms of messages.

\section{Conclusion}

The digital literacy capacity of the people in Indonesia is still low. These challenges can be overcome by presenting literature digitally in order to attract readers to literate. The digitization of literature plays an important role in (1) attracting reading interest, (2) increasing readers' love for digital information, (3) avoiding digital hoax information, and (4) inventorying literature digitally. Digital literacy means understanding and using information from various digital sources including the ability to access, analyze, evaluate, and communicate information in various forms of messages.

\section{References}

[1] Buckingham, David. "Going Critical: The Limits of Media Literacy". Dimuat dalam The Journal of Education. Volume: 37 issue: 2, page (s): 142-152. https://doi.org/10.1177/000494419303700203. (2003).

[2] Klein, Marven L, Peterson, Susan dan Linda Siminton. Teaching Reading in the Elementary Grades. Allyn and Bacon: USA. (1991).

[3] Mathar, Taufiq. Authors Collaboration in Digital Literacy from 1997 to 2013: a Bibilometric Study. diakses dalam http://journal.uinalauddin.ac.id/index.php/khizanah-alhikmah/article/download/131/105; 2013. (2014).

[4] Kurnianingsih, I., Rosini, R., \& Ismayati, N. Upaya Peningkatan Kemampuan Literasi Digital Bagi Tenaga Perpustakaan Sekolah dan Guru di Wilayah Jakarta Pusat Melalui Pelatihan Literasi Informasi. Jurnal Pengabdian Kepada Masyarakat, 3(1), 61-76. https://doi.org/10.22146/jpkm.25370. (2017).

[5] Setianingsih, Anjar. 2012. "Pembelajaran Sastra Tradisional di Sekolah Guna Menumbuhkan Kecintaan terhadap Kebudayaan Indonesia". Prosiding Konferensi Internasional Kesusastraan XXII UNY-HISKI. Halaman 95-104.

[6] Udu, Sumiman. 2015. "Tradisi Lisan Bhanti-Bhanti sebagai Media Komunikasi Kultural dalam Masyarakat Wakatobi”. Dimuat dalam Jurnal Humaniora Volume 27, No 1 Februari 2015, hal. 53-66.

[7] A’yuni, Qory Qurratun. Literasi Digital Remaja di Kota Surabaya (Studi Deskriptif tentang Tingkat Kompetensi Literasi Digital pada Remaja SMP, SMA dan Mahasiswa di Kota Surabaya). http://journal.unair.ac.id/download-fullpapersln53e61a7e60full.pdf; (2018).

[8] Riel, J., Christian, S., \& Hinson, B. Charting digital literacy: A framework for information technology and digital skills education in the community college.Presentado en Innovations; (2012).

[9] Martin, Allan. Digital Literacy and the 'Digital Society' dalam Lankshear, C and Knobel, M (ed). Digital literacies: concepts, policies and practices. Die Deutsche Bibliothek; (2008).

[10] Penguatan Literasi Digital Melalui Pemanfaatan E-Learning”. Jurnal ASPIKOM, Volume 3 Nomor 6, Januari, hlm 1200-1214. (2019). 
[11] Tamburaka, Apriadi. Literasi Media: Cerdas Bermedia Khalayak Media Massa. Jakarta: Raja Grafindo Persada. (2013).

[12] Herlina, Dyna. Membangun Karakter Bangsa Melalui Literasi Digital. http://staffnew.uny.ac.id/upload/132309682/pengabdian/membangun-karakter-bangsamelalui-literasi-digital.pdf. (2017). 